\title{
HUBUNGAN PENYULUHAN KESEHATAN REPRODUKSI REMAJA DENGAN PERSEPSI SISWA TENTANG SEKSUALITAS REMAJA PADA KELAS XI SMA NEGERI 1 JEJANGKIT KECAMATAN JEJANGKIT KABUPATEN BARITO KUALA
}

\author{
Mardiah $^{1}$, Muflihah ${ }^{2}$,Rein laily ${ }^{3}$ \\ Akademi Kebidanan Abdi Persada Banjarmasin \\ Email : akbidabdipersda@yahoo.com
}

\begin{abstract}
ABSTRAK
Remaja mulai ingin tahu tentang kehidupan seksual manusia dengan mencari informasi tentang seks, baik melalui buku, film atau gambar-gambar lain yang dilakukan dengan sembunyi sembunyi. Hal ini dilakukan remaja karena kurang terjalinya komunikasi yang bersifat dialogis antara remaja dengan orang dewasa, baik orang tua ataupun guru mengenai masalah seksual, dimana kebanyakan masyarakat masih mengangap tabu untuk membicarakan maslah seksual dalam kehidupan sehari-hari. Tujuan penelitian ini untuk mengetahui hubungan penyuluhan kesehatan reproduksi remaja dengan persepsi siswa tentang seksualitas remaja pada kelas XI SMA Negeri 1 Jejangkit Kecamatan Jejangkit Kabupaten Barito Kuala. Penelitian ini merupakan quasi eksperimental dengan metode pree test post test. Sampel yang digunakan sebanyak 63 responden dari siswa kelas XI SMA Negeri 1 Jejangkit. Berdasarkan hasil penelitian tentang hubungan penyuluhan kesehatan reproduksi remaja dengan persepsi siswa tentang seksualitas remaja pada kelas XI SMA Negeri 1 Jejangkit Kecamatan Jejangkit Kabupaten Barito Kuala dapat disimpulkan bahwa: Hasil pre test diperoleh nilai 6,17 lebih rendah dari nilai posttest sebesar 8,55 setelah dilakukan penyuluhan kesehatan reproduksi remaja pada siswa. Persepsi siswa kelas XI SMA Negeri Jejangkit tentang seksualitas remaja sesudah diberikan penyuluhan kesehatan reproduksi remaja, mengalami peningkatan dimana di dominansi oleh kategori tinggi, hal ini menunjukan bahwa persepsi tentang seksualitas yang dimiliki siswa sudah baik, sehingga siswa akan memiliki perilaku yang benar dalam ruang lingkup seksualitas karena persepsi yang baik dari kegiatan mengikuti penyuluhan sehingga memiliki perilaku yang benar dalam ruang lingkup seksualitas karena persepsi yang baik.
\end{abstract}

Kata kunci :Remaja, Kesehatan reproduksi, seksualitas, persepsi

\begin{abstract}
students of SMA Negeri 1 Jejangkit. Based on the results of research on the relationship of adolescent reproductive health counseling with students' perceptions of adolescent sexuality in class XI of SMA Negeri 1 Jejangkit Jejangkit District Barito Kuala, it can be concluded that: The pre-test results obtained 6.17 values lower than the posttest value of 8.55 after it was conducted counseling on adolescent reproductive health in students. Perception of Grade XI students of SMA Negeri Jejangkit about adolescent sexuality after being given counseling on adolescent reproductive health, which has increased where dominance by high categories, this shows that perceptions of sexuality that students have are good, so students will have the right behavior within the scope of sexuality because a good perception of the activity follows counseling so that it has the right behavior in the scope of sexuality because of good perception.
\end{abstract}

Keywords: Teenagers, Reproductive health, sexuality, perception

\section{PENDAHULUAN}

Masa remaja (usia 11-20 tahun) adalah masa yang khusus dan penting, karena merupakan periode pematangan organ reproduksi manusia. Masa remaja disebut juga masa pubertas. Kesehatan masa remaja adalah definisi kesehatan reproduksi yaitu suatu keadaan sejahtera fisik, mental, dan sosial secara utuh, tidak semata-mata bebas dari penyakit atau kecacatan dalam semua hal yang berkaitan dengan sistem reproduksi, serta fungsi dan prosesnya. Definisi ini sejalan dengan yang ada di Undang-Undang Nomor 36/2009 tentang Kesehatan yang menyatakan bahwa kesehatan reproduksi adalah keadaan sehat secara fisik mental dan sosial secara utuh tidak semata-mata 
bebas dari penyakit dan kecacatan yang berkaitan dengan sistem reproduksi perempuan (Sulistyoningtyas S et al, 2016).

Remaja atau adolescence berasal dari bahasa latin adolescere yang berarti tumbuh ke arah kematangan. Kematangan yang dimaksud adalah bukan hanya kematang fisik saja, tetapi juga kematang sosial dan psikologis. Batasan usia remaja menurut WHO adalah 12 sampai 24 tahun. Menurut Depkes RI adalah antara 10 sampai 19 tahun dan belom kawin. Menurut BKKBN adalah 10 sampai 19 tahun (Widyastuti et al, 2009).

Masa remaja adalah masa dimana seorang individu mengalami peralihan dari masa kanakkanak ke masa dewasa disertai dengan perubahan baik fisik, psikis maupun perilaku secara radikal, sehingga remaja mulai bertanyatanya mengenai berbagai fenomena yang terjadi di lingkungan sekitarnya sebagai dasar bagi pembentukan nilai diri mereka.

Sejak masa remaja pada diri seorang anak terlihat adanya perubahan-perubahan pada bentuk tubuh yang disertai dengan perubahan struktur dan fungsi. Pematangan kelenjar pituitari berpengaruh pada proses pertumbuhan tubuh sehingga remaja mendapat ciri-ciri sebagai laki-laki dewasa dan sebagai perempuan dewasa.

Masa remaja diawali oleh masa pubertas, yaitu masa terjadinya perubahan- perubahan fisik (meliputi penampilan fisik seperti bentuk tubuh dan proporsi tubuh) dan fungsi fisiologis (kematangan organ-organ seksual). Perubahan tubuh ini disertai dengan perkembangan bertahap dari karakteristik seksual primer dan karakteristik seksual sekunder.

Karakteristik seksual primer mencakup perkembangan organ-organ reprodiksi, sedangkan karakteristik seksual sekunder mencakup perubahan bentuk tubuh sesuai dengan jenis kelamin, misalnya: pada remaja putri ditandai dengan pembesaran buah dada dan pinggul; sedangkan pada remaja laki-laki mengalami pembesaran suara, tumbuh bulu dada, bulu kaki, serta kumis.

Tugas perkembangan seksualitas remaja mencakup orientasi seksual dan peran seksual pada remaja. Orientasi seksual ditandai dengan ketertarikan remaja terhadap segala informasi yang berkaitan dengan seks dan lawan jenis. Sedangkan peran seks adalah menerima dan mengembangkan peran serta kemampuan tertentu sesuai dengan jenis kelaminnya (gender), yaitu sebagai laki-laki bertingkah laku dan bersikap selayaknya laki-laki dan mengetahui peran sebagai laki-laki, sebagaimana perempuan bersikap dan bertingkah laku selayaknya perempuan dan mengetahui peranperan sebagai perempuan.

Remaja mulai ingin tahu tentang kehidupan seksual manusia. Untuk itu, mereka mencari informasi tentang seks, baik melalui buku, film atau gambar-gambar lain yang dilakukan dengan sembunyi sembunyi. Hal ini dilakukan remaja karena kurang terjalinya komunikasi yang bersifat dialogis antara remaja dengan orang dewasa, baik orang tua ataupun guru mengenai masalah seksual, di mana kebanyakan masyarakat masih mengangap tabu untuk membicarakan maslah seksual dalam kehidupan sehari-hari.

Sejalan meningkatnya minat terhadap kehidupan seksual, remaja selalu berusaha mencari informasi obyektif mengenai seks. Oleh karena itu hal yang paling membahayakan adalah bila informasi yang diterima remaja berasal dari sumber yang kurang tepat sehingga akhirnya remaja mempersepsikanya dengan salah. Hal ini merupakan akibat kekurang pahaman remaja terhadap masalah seputar seksualitas.

Kekurang pahaman ini akan memunculkan perilaku seksual remaja yang tidak bertanggung jawab, seperti melakukan eksperimen ke lokasi pekerja seks komersial, melakukan seks pranikah, melakukan oral seks dan sebagainya, tanpa pertimbangan kemungkinan masa depan yang kurang cerah pada dirinya. Keadaan ini tampak sudah meluas pula di kalangan remaja indonesia.

Saat ini masih banyak di jumpai penyakit infeksi yang menggangu alat reproduksi wanita. Beberapa penelitian menunjukkan bahwa remaja indonesia beresiko untuk terkena infeksi PMS. Survei surveilansi perilaku yang di adakan universitas indonesia menunjukkan bahwa 2,8 \% pelajar SMA wanita adanya gejala-gejala PMS. (Muin M et al, 2013 ).

Organ reproduksi merupakan daerah tertutup dan berlipat sehingga lebih mudah untuk berkeringat, lembab, dan kotor. Sikap dan perilaku yang buruk dalam menjaga kebersihan genitalia, seperti mencucinya dengan air kotor, memakai pembilas secara berlebihan, menggunakan celana yang tidak menyerap keringat, jarang mengganti celana dalam, dan tak sering mengganti pembalut dapat menjadi pencetus timbul infeksi. Jadi, pengetahuan dan sikap dalam menjaga kebersihan genitalia eksternal merupakan faktor penting dalam pencegahan infeksi (Sulistyoningtyas S et al, 2016).

Kesehatan reproduksi menurut WHO adalah kesejahteraan fisik, mental dan sosial, yang utuh bukan hanya bebas dari penyakit atau kecacatan, dalam segala aspek yang berhubungan dengan sistem reproduksi, fungsi serta prosesnya. (Yanti, 
2011).

Permasalahan kesehatan reproduksi remaja termasuk pada saat pertama anak perempuan haid yang bisa beresiko timbulnya anemia, perilaku seksual yang mana bila kurang pengetahuan dapat tertular penyakit hubungan seksual. Remaja yang menginjak masa dewasa bila kurang pengetahuan dapat mengakibatkan resiko kehamilan usia muda yang mana mempunyai resiko terhadap kesehatan ibu hamil dan janinnya (widyastuti et al, 2009).

Pada tahun 2015 ada total 229.715 bayi yang lahir dari wanita yang berusia 15 sampai 19 tahun. Pada kelompok usia wanita tersebut persentasi kelahiran adalah 22,3 per 1000 wanita (CDC, 2015). Survei Kesehatan Remaja Indonesia (SKRRI) 2002-2003 yang dilakukan oleh BPS menyebutkan laki-laki berusia 20-24 tahun belum menikah pernah melakukan hubungan seksual sebanyak $57,5 \%$ dan yang berusia $15-19$ tahun sebanyak $43,8 \%$. Sedangkan perempuan berusia 20-24 tahun belum menikah pernah melakukan hubungan seksual sebanyak $63 \%$ dan yang berusia 15-19 tahun pernah melakukan hubungan seksual sebanyak $42,3 \%$. Hasil studi PKBI sejak tahun 2000-2003 dari 37.000 kasus KTD, ternyata $27 \%$ diantaranya belum menikah, termasuk $12,5 \%$ diantaranya masih berstatus pelajar atau mahasiswa (Okanegara, 2008).

Hal ini dapat menimbulkan masalah besar pada diri remaja, tentu saja Informasi yang tepat sangat dibutuhkan dalam perkembangan remaja, perkembangan yang sangat pesat pada remaja baik mental maupun fisik membutuhkan pengetahuan tentang psikologi dan biologi agar kebutuhanya dapat tercapai dengan optimal. Maka dari itu perlu adanya pendidikan mengenai seksual pada remaja terutama mengenai kesehatan reproduksi remaja (KRR) melalui penyuluhan sehingga remaja mengetahui informasi tentang perkembangan reproduksi seksual yang benar dan tidak terjerumus pada persepsi yang salah mengenai seksualitas remaja.

Persepsi sendiri merupakan cara pandang dalam diri individu yang dimulai dengan diterimanya rangsangan, sampai rangsangan itu disadari dan dimengerti oleh individu sehingga individu dapat mengenali dirinya sendiri dan keadaan di sekitarnya. Pemahaman dan persepsi yang salah pada remaja mengenai seks dapat menjerumuskan remaja dalam tindakan yang salah yaitu mencoba untuk melakukan perilaku seksual remaja yang tidak sesuai tugas perkembangan seksualitas remaja. Tindakan seksual yang tidak sesuai perkembangan remaja sendiri dapat berdampak buruk terhadap remaja mulai dampak psikologis hingga dampak secara klinis.

Persepsi siswa mengenai seksualitas haruslah positif agar remaja dapat bertingkah laku positif, sehingga remaja dapat berkembang menjadi individu dewasa yang matang secara fisik maupun mental. Tingkah laku yang menunjukan sikap positif terhadap seksualitas adalah sebagai berikut : 1) menempatakan seks sesuai fungsi dan tujuan, 2) tidak menganggap seks itu jijik, tabu, dan jorok, 3) tidak dijadikan candaan dan bahan obrolan murahan 4) mengikuti norma dan aturan dalam menggunakanya, 5) Membicarakan seks dalam konteks ilmiah atau belajar untuk memahami diri dan orang lain, serta pemanfaatan secara baik dan benar sesuai dengan fungsi dan tujuan sakralnya.

Persepsi yang salah mengenai seksualitas diantaranya disebabkan pengetahuan seksnya yang sangat kurang, misalnya remaja menganggap alat kelamin merupakan bagian tubuh yang kotor dan tidak boleh disentuh, alat kelamin merupakan organ tubuh sama seperti yang lain jika tidak boleh disentuh atau dibersihkan, maka dalam waktu yang lama akan menyebabkan infeksi dan mempengaruhi kesehatan. Contoh lain adalah minum minuman bersoda akan mempercepat selesainya menstruasi dan berhubungan seksual dengan pacara merupakan bukti cinta dankasih sayang. Hal-hal tersebut bisa terjadi di kalangan remaja karena ketidaktahuan dan informasi yang setengah-setengah serta dari sumber yang tidak jelas.

Survei Kesehatan Reproduksi Remaja 2012 (dalam BkkbN.com situs resmi BkkbN) mengungkap beberapa perilaku berpacaran remaja yang belum menikah, antara lain, sebanyak 29,5 persen remaja pria dan 6,2 persen remaja wanita pernah meraba atau merangsang pasangannya, sebanyak 48,1 persen remaja laki-laki dan 29,3 persen remaja wanita pernah berciuman bibir, sebanyak 79,6 persen remaja pria dan 71,6 persen remaja wanita pernah berpegangan tangan dengan pasangannya.

Selain itu, pernikahan dini seringkali dilakukan oleh kaum remaja dikarenakan karena kurangnya pengetahuan ataupun karena dorongan orang tua. Kalimantan Selatan menjadi provinsi dengan angka pernikahan dini tertinggi di Indonesia dengan usia pernikahan lebih muda dibandingkan provinsi-provinsi. Kondisi pernikahan dini yang terjadi karena kecelakaan atau kehamilan yang tidak dikehendaki. Berdasarkan data BKKBN, jumlah keluarga remaja di Kalimantan Selatan adalah 2.483 orang. (Tempo.com, 2013)

Berdasarkan wawancara awal dengan guru BK di SMA Negeri 1 Jejangkit Kecamatan Jejangkit 
Kabupaten Barito Kuala, ditemukan sebagian siswa tidak paham mengenai kesehatan reproduksi, dan tidak mendapatkan informasi khusus mengenai kesehatan reproduksi remaja. Di samping itu sudah banyak siswa yang sudah berpacaran dan tentu saja masa-masa remaja seperti itu rentan terjerumus pada hal-hal yang dapat merugikan siswa sendiri. Dan data terakhir diperoleh ada 3 siswa SMA Negeri 1 Jejangkit melakukan pernikahan dini sebanyak 3 orang setelah lulus sekolah.

Peneliti juga melakukan studi pendahuluan dengan menyebarkan kuesioner kepada siswa SMA Negeri 1 Jejangkit secara acak. Setelah menganalisis kuesioner yang telah disebarkan hasilnya sebagai berikut siswa $65 \%$ mempunyai kebiasaan mencari informasi yang berkaitan dengan kesehatan, namun informasi yang didapatkan 95\% diperoleh dari internet, 85\% siswa juga mengungkapkan pernah berpacaran dan $70 \%$ mengatakan bahwa masih dalam status berpacaran.

Rata-rata siswa pertama berpacaran yaitu antara usia 11-17 tahun, umur 12-15 tahun merupakan frekuensi terbanyak siswa pertama kali berpacaran, $75 \%$ siswa juga mengungkapkan orang tua tidak mengetahui mereka berpacaran. Menurut siswa penyebab remaja melakukan hubungan seksual pranikah $80 \%$ disebabkan karena faktor pergaulan dan $50 \%$ juga mengatakan bahwa minimnya pengetahuan kesehatan reproduksi menjadi alasanya.

Kesehatan reproduksi remaja (KRR) adalah suatu kondisi sehat yang menyangkut sistem, fungsi dan proses reproduksi yang dimiliki oleh remaja. Pengertian sehat disini tidak sematamata bebas penyakit atau bebas dari kecacatan tetapi sehat secara mental, sosial dan kultural. Pengetahuan mengenai kesehatan reproduksi remaja akan diberikan melalui layanan informasi salah satunya dengan memberikan penyuluhan.

Berdasarkan uraian diatas penulis tertarik mengambil judul dalam penelitian ini yaitu "Hubungan Penyuluhan Kesehatan Reproduksi Remaja Dengan Persepsi Siswa Tentang Seksualitas Remaja Pada Kelas XI SMA Negeri 1 Jejangkit Kecamatan Jejangkit Kabupaten Barito Kuala".

\section{Metode Penelitian \\ Rancangan Penelitian}

Penelitian ini merupakan penelitian Quasi eksperimental (interventional) dengan metode pre test dan post-test design, yaitu menilai tingkat pengetahuan dan sikap remaja puteri sebelum dan sesudah penyuluhan kesehatan.

\section{Tempat Dan Waktu Penelitian}

Penelitian ini dilaksanakan di SMA Negeri 1 Jejangkit, Kecamatan jejangkit Kabupaten Barito Kuala. Penelitian ini dilaksanakan selama bulan Maret-November 2018, sedangkan pengambilan dan pengumpulan data dilakukan selama bulan Juni-November 2017.

\section{Populasi Dan Sampel Penelitian}

Populasi pada penelitian ini adalah siswa kelas XI yang memenuhi kriteria inklus dan eksklusi. Populasi pada penelitian ini berjumlah sekitar 170 orang. Teknik pengambilan sampel dilakukan dengan cara nonprobability sampling. Rumus yang di gunakan dalam penentuan besar sampel adalah sebagai berikut :

Keteragan :

$$
\mathrm{n}=\frac{\mathrm{N}}{1+\mathrm{N}(\mathrm{e}) 2}
$$

$\mathrm{n} \quad=$ Jumlah Sampel

$\mathrm{N} \quad=$ Ukuran Sampel

e = Tingkat kesalahan pengambilan sampel yang masih dapat ditolerir (misalnya, 1\%, 5\%, 10\%, dan lain-lain).

Berdasarkan rumus di atas dapat diketahui jumlah sampel dengan cara :

$\mathrm{n}=\frac{170}{1+170(0,1)^{2}}$

$=62,96 \Rightarrow$ dibulatkan menjadi 63 responden

Setelah dilakukan perhitungan dengan diketahui jumlah populasi pada kelas XI SMA Negeri 1 Jejangkit berjumlah 170, maka didapati besar sampel sebanyak 63 orang karena semakin banyak sampel yang diambil semakin mendekati kebenaran.

Terdapat beberapa kriteria inklusi dan eksklusi dalam penelitian ini. Adapun kriteria inklusi adalah sebagai berikut:

a. Sekolah SMA Negeri 1 Jejangkit

b. Wanita

c. Usia 16-18 tahun

d. Memahami bahasa Indonesia.

e. Sehat jasmani dan rohani.

f. Bersedia di ikusertakan dalam penelitian.

Sedangkan kriteria ekslusi yang digunakan adalah sebagai berikut:

a. Tidak bersedia diikutsertakan dalam penelitian.

b. Berhalangan hadir pada saat penelitian dilakukan

\section{Teknik Pengumpulan Data}


Untuk memperoleh data penelitian yang dilakukan peneliti adalah:

1) Terlebih dahulu peneliti meminta database siswa yang terdapat disekolah tersebut.

2) Setelah diperoleh data siswa maka peneliti mengambil populasi kelas XI yang akan dihitung sampel. Setelah dihitung sampel yang akan dibutuhkan, maka peneliti melakukan pengambilan sampel kesekolah tersebut.

3) Cara pengambilan sampel adalah dengan mendata siswi yang berusia 16-18 tahun.

4) Meminta persetujuan responden untuk dilakukan penelitian dan menjelaskan tentang prosedur penelitian.

5) Apabila responden bersedia, maka responden tersebut menjadi sampel.

6) Peneliti membagikan kuesioner kepada responden dan meminta responden mengisi dan diberikan waktu selama 15 menit. Dan mengambil kuesioner yang telah dijawab responden.

7) Peneliti memberikan penyuluhan kesehatan reproduksi kepada responden dan membuka sesi tanya jawab

8) Peneliti membagikan kuesioner yang kedua dan meminta responden untuk mengisi kembali dan di berikan waktu selama 15 menit.

Kemudian dinilai

Metode pengumpulan data pada prinsipnya berfungsi untuk mengungkapkan variabel yang akan diteliti. Dalam penelitian ini data yang akan diungkap berupa aspek psikologi yaitu persepsi siswa tentang seksualitas. Metode pengumpulan data yang digunakan dalam penelitian ini adalah skala psikologi dan alatnya adalah skala persepsi siswa.

Dalam penelitian ini skala yang digunakan adalah skala Likert. Skala likert memiliki lima kategori kesetujuan dan memiliki skor 1-5, akan tetapi dalam penelitian ini menggunakan jawaban kesesuaian karena kesesuaian lebih tepat untuk menggambarkan keadaan yang diteliti sekarang. Skor skala likert dalam penelitian ini berkisar antara 1-4 dengan asumsi untuk mempermudah subjek penelitian dalam memilih jawaban. Skala yang digunakan dalam penelitian ini mempunyai 4 alternatif jawaban yaitu "sangat setuju", "setuju", "tidak setuju", dan "sangat tidak setuju".

Selanjutnya untuk menginterpretasikan tingkat persepsi siswa, maka jumlah skor tiap responden ditransformasi dalam bentuk persentase skor dengan cara membagi dengan skor idealnya dan dikalikan dengan 100\%. Selanjutnya porsentase skor tersebut dibandingkan dengan kriteria persepsi siswa kemudian akan diperoleh kriteria sangat tinggi, tinggi, sedang, rendah dan sangat rendah. Kriteria tingkat persepsi siswa sebagai berikut:

Prosentase skor maksimum $=(4: 4)$ x $100 \%=100 \%$

Prosentase skor minimum $=(1: 4) \times 100 \%=25 \%$ Rentang prosentase $\quad=100 \%-25 \%=75 \%$ Banyaknya kriteria ada lima tingkatan yaitu sangat tinggi, tinggi, sedang, rendah, sangat rendah.

Panjang kelas interval $=$ Rentang:Banyak Kriteria

$$
=75 \%: 5=15 \%
$$

\section{Kriteria Penilaian Tingkat Persepsi Siswa}

\begin{tabular}{|c|c|}
\hline Interval \% & Kriteria \\
\hline $85 \%-100 \%$ & Sangat Tinggi \\
\hline $70 \%-84 \%$ & Tinggi \\
\hline $55 \%-69 \%$ & Sedang \\
\hline $40 \%-54 \%$ & Rendah \\
\hline $25 \%-39 \%$ & Sangat Rendah \\
\hline
\end{tabular}

\section{HASIL PENELITIAN \\ Deskripsi karakteristik Sampel}

Sampel penelitian ini adalah siswa yang telah memenuhi kriteria inklusi dan eksklusi yang telah ditetapkan oleh peneliti. Jumlah sampel didalam penelitian ini adalah 63 orang. Cara memperoleh data dilakukan dengan kuesioner, dimana pemberian kuesioner kepada responden dilakukan dua tahap. Tahap pertama pengisian kuesioner dilakukan sebelum peneliti melakukan penyuluhan kesehatan reproduksi, sedangkan tahap kedua untuk pengisian kuesioner yang diberikan setelah pemberian penyuluhan kesehatan reproduksi.

Tabel 4.1

Karakteristik Sampel Penelitian

\begin{tabular}{cccc}
\hline $\begin{array}{c}\text { Karakteristik } \\
\text { Usia }\end{array}$ & $\begin{array}{c}\text { Jenis } \\
\text { Kelamin }\end{array}$ & Frekuensi & $\begin{array}{c}\text { Persentase } \\
(\%)\end{array}$ \\
\hline 16 Tahun & $\mathrm{L}$ & 6 & 9,5 \\
& $\mathrm{P}$ & 11 & 17,5 \\
17 tahun & $\mathrm{L}$ & 19 & 30,1 \\
& $\mathrm{P}$ & 22 & 34,9 \\
18 Tahun & $\mathrm{L}$ & 2 & 3,2 \\
& $\mathrm{P}$ & 3 & 4,8 \\
Total & & 63 & 100 \\
\hline
\end{tabular}

Sumber: Data Primer 
Berdasarkan tabel diatas bahwa karakteristik siswa kelas XI SMA Negeri1 Jejangkit dengan jumlah responden 63 orang yaitu mayoritas responden yaitu perempuan usia 17 tahun $(34,9 \%)$, laki-laki usia 17 tahun $(30,1 \%)$, perempuan usia 16 tahun (17,5\%), laki-laki usia 16 tahun $(9,5 \%)$, perempuan usia 18 tahun $(4,8 \%)$ dan lakilaki usia 18 tahun (3,2\%). Dimana mayoritas usia yang paling besar yaitu 17 tahun, usia ini berada pada tahap perkembangan sosial dan emosional yang mudah dibangkitkan semangatnya (Budiman, 2007).

\section{Analisis Univariat}

Berdasarkan hasil pretest dan post test yang dilaksanakan sebelum dan sesudah penyuluhan mengenai kesehatan reproduksi remaja, maka diperoleh frekuensi responden sebagai berikut:

\section{Frekuensi Responden Berdasarkan Hasil Test}

\begin{tabular}{llll}
\hline & Mean & $\begin{array}{l}\text { Standar } \\
\text { Deviasi }\end{array}$ & $\mathrm{P}$ \\
\hline Pre & 6,17 & 0,516 & 0.000 \\
Test & 8,55 & 0,679 & \\
Post & & & \\
Test & & & \\
\hline
\end{tabular}

\section{Sumber: Data Primer}

Berdasarkan tabel diatas terlihat bahwa ada pengaruh penyuluhan kesehatan reproduksi terhadap pengetahuan siswa kelas XI SMA Negeri 1 Jejangkit. Nilai mean dari pengetahuan pretest sebesar 6,17 dan pengetahuan posttest sebesar 8,55 . Sehingga pada posttest terjadi peningkatan nilai rata-rata, hal ini juga mempengaruhi pengetahuan responden. Banyak hal yang dapat mempengaruhi pengetahuan seseorang yaitu informasi yang didapat baik dari pendidikan formal maupun informal, selain itu juga umur sangat mempengaruhi terhadap daya tangkap dan pola pikir seseorang. Semakin bertambah usia akan semakin berkembang pula daya tangkap dan pola pikirnya, sehingga pengetahuan yang diperolahnya semakin membaik (Notoatmojo, 2007). Maka dari itu, untuk meningkatkan pengetahuan seseorang dapat dilakukan dengan melaksanakan pendidikan kesehatan yaitu kegiatan-kegiatan edukasi yang dilakukan oleh tenaga kesehatan maupun lainnya, berupa penyuluhan atau pendidikan kesehatan.

\section{Frekuensi Responden Berdasarkan Persepsi}

\begin{tabular}{llll}
\hline & Mean & $\begin{array}{l}\text { Standar } \\
\text { Deviasi }\end{array}$ & $\mathrm{P}$ \\
\hline Sebelum & 2,17 & 1,086 & 0.000 \\
Sesudah & 3,73 & 1,019 & \\
\hline
\end{tabular}

journal.umbjm.ac.id/index.php/midwiferyandreproduction

\section{Sumber: Data Primer}

Berdasarkan tabel diatas terlihat bahwa ada pengaruh penyuluhan kesehatan reproduksi terhadap persepsi siswa kelas XI SMA Negeri 1 Jejangkit. Nilai mean dari persepsi siswa sebelum penyuluhan sebesar 2,17 dan persepsi siswa sesudah penyuluhan sebesar 3,73. Sehingga pada persepsi sesudah penyuluhan mengalami peningkatan nilai ratarata. Dengan persepsi secara minimal, masyarakat memiliki pola berpikir tertentu dan pola berpikir diharapkan dapat berubah dengan diprolehnya pengalaman, pendidikan, dan pengetahuan, melalui interaksi lingkungan (Maulana HDJ, 2009).

\section{Analisis Bivariat}

Dalam penelitian ini analisis bivariat dilakukan untuk mengetahui hubungan penyuluhan kesehatan reproduksi remaja dengan persepsi siswa tentang seksualitas remaja pada kelas XI SMA Negeri 1 Jejangkit Kecamatan Jejangkit Kabupaten Barito Kuala dengan menggunakan Uji chi square dengan hasil sebagai berikut:

\section{Persepsi Siswa Sebelum Penyuluhan berdasarkan Jenis Kelamin}

\begin{tabular}{|c|c|c|c|c|c|}
\hline & \multicolumn{2}{|c|}{ Jenis Kelamin } & \multirow[t]{2}{*}{ Total } & \multirow{2}{*}{$\begin{array}{c}\text { Persenta } \\
\text { se }(\%)\end{array}$} \\
\hline & & $\begin{array}{l}\text { Laki- } \\
\text { Laki }\end{array}$ & $\begin{array}{l}\text { Perempu } \\
\text { an }\end{array}$ & & \\
\hline Persepsi & Sangat & 10 & & 10 & 30,2 \\
\hline Siswa & Rendah & 10 & $y$ & 19 & \\
\hline Tentang & Rendah & 10 & 14 & 24 & 38,1 \\
\hline Seksualita & Sedang & 6 & 7 & 13 & 20,6 \\
\hline s Remaja & Tinggi & 1 & 3 & 4 & 6,3 \\
\hline $\begin{array}{l}\text { Sebelum } \\
\text { Penyuluha } \\
n\end{array}$ & $\begin{array}{l}\text { Sangat } \\
\text { Tinggi }\end{array}$ & 0 & 3 & 3 & 4,8 \\
\hline Total & & 27 & 36 & 63 & 100 \\
\hline
\end{tabular}

Sumber: Data Primer

Berdasarkan data tabel diatas mengenai persepsi siswa kelas XI SMA Negeri Jejangkit tentang seksualitas remaja sebelum diberikan penyuluhan masuk kategori sangat rendah 30,2\%, kategori rendah $38,1 \%$, kategori sedang $20,6 \%$, kategori tinggi $6,3 \%$ dan kategori sangat tinggi $4,8 \%$.

\section{Persepsi Siswa Sesudah Penyuluhan berdasarkan Jenis Kelamin}




\begin{tabular}{|c|c|c|c|c|c|}
\hline & \multicolumn{2}{|c|}{ Jenis Kelamin } & \multirow[t]{2}{*}{ Total } & \multirow{2}{*}{$\begin{array}{c}\text { Persenta } \\
\text { se }(\%)\end{array}$} \\
\hline & & $\begin{array}{l}\text { Laki- } \\
\text { Laki }\end{array}$ & $\begin{array}{c}\text { Perempu } \\
\text { an }\end{array}$ & & \\
\hline $\begin{array}{l}\text { Persepsi } \\
\text { Siswa }\end{array}$ & $\begin{array}{l}\text { Sangat } \\
\text { Rendah }\end{array}$ & 2 & 1 & 3 & 4,8 \\
\hline Tentang & Rendah & 4 & 0 & 4 & 6,3 \\
\hline Seksualitas & Sedang & 4 & 9 & 13 & 20,6 \\
\hline Remaja & Tinggi & 12 & 18 & 30 & 47,7 \\
\hline $\begin{array}{l}\text { Sesudah } \\
\text { Penvuluhan }\end{array}$ & $\begin{array}{l}\text { Sangat } \\
\text { Tingai }\end{array}$ & 5 & 8 & 13 & 20,6 \\
\hline Total & & 27 & 36 & 63 & 100 \\
\hline
\end{tabular}

Sumber: Data Primer

Berdasarkan data tabel diatas mengenai persepsi siswa kelas XI SMA Negeri Jejangkit tentang seksualitas remaja sesudah diberikan penyuluhan masuk kategori sangat rendah 4,8\%, kategori rendah 6,3\%, kategori sedang 20,6\%, kategori tinggi $47,7 \%$ dan kategori sangat tinggi $20,6 \%$.

\section{Pembahasan \\ Hubungan penyuluhan kesehatan reproduksi remaja dengan persepsi siswa tentang seksualitas remaja pada kelas XI SMA Negeri 1 Jejangkit Kecamatan Jejangkit Kabupaten Barito Kuala}

Berdasarkan data mengenai hubungan penyuluhan kesehatan reproduksi remaja dengan persepsi siswa tentang seksualitas remaja pada kelas XI SMA Negeri 1 Jejangkit Kecamatan Jejangkit Kabupaten Barito Kuala, dari hasil pree test diperoleh nilai 6,17 yaitu sebelum dilakukan penyuluhan kesehatan reproduksi remaja pada siswa kelas XI SMA Negeri 1 Jejangkit, dan nilai posttest sebesar 8,55 setelah dilakukan penyuluhan kesehatan reproduksi remaja pada siswa. Berdasarkan nilai test tersebut, bahwa penyuluhan kesehatan reproduksi yang dilakukan mempengaruhi pengetahuan siswa tentang kesehatan reproduksi remaja. Tujuan kegiatan penyuluhan kesehatan yaitu untuk mencapai tujuan hidup sehat dengan cara mempengaruhi prilaku masyarakat baik itu secara individu ataupun kelompok dengan menyampaian pesan (Maulana, 2007). Penyuluhan kesehatan merupakan gabungan dari berbagai kegiatan dan kesempatan yang berlandaskan prinsip-prinsip belajar sehingga harapannya dengan adanya penyuluhan kesehatan dapat membuat masyarakat lebih sadar akan pentingnya pola kehidupan yang sehat (Absah, 2011).

Sementara untuk persepsi siswa kelas XI SMA Negeri 1 Jejangkit tentang seksualitas remaja sebelum diberikan penyuluhan kesehatan reproduksi remaja sebesar 2,17 dan persepsi siswa tentang seksualitas remaja sesudah penyuluhan sebesar 3,73. Nilai persepsi ini menunjukkan adanya peningkatan, sehingga kegiatan penyuluhan kesehatan reproduksi remaja mempunyai pengaruh dalam merubah persepsi siswa mengenai seksualitas remaja mengalami peningkatan nilai rata-rata. Robbins (2003) menyatakan bahwa persepsi merupakan sebuah proses yang ditempuh masing-masing individu untuk mengorganisasikan serta menafsirkan kesan dari indera yang anda miliki agar memberikan makna kepada lingkungan sekitar. Banyak faktorfaktor yang dapat mempengaruhi sebuah persepsi, mulai dari pelaku persepsi, objek yang dipersepsikan serta situasi yang ada.

Persepsi seseorang dipengaruhi oleh pengetahuan atau informasi yang disampaikan sehingga seseorang tersebut mampu menafsirkan dan mendeskripsikan. Disamping itu ada faktorfaktor lain yang mampu mempengaruhi, menurut Gibson, dkk dalam Rahmatullah (2014:11-13), ada 2 faktor yang mempengaruhi persepsi, faktor tersebut adalah sebagai berikut: 1) Fakor internal yang mempengaruhi persepsi, yaitu faktor-faktor yang terdapat dalam diri individu; 2) Faktor eksternal yang mempengaruhi persepsi, merupakan karakteristik dari lingkungan dan obyek-obyek yang terlihat didalamnya.

Berdasarkan kategori persepsi tentang seksualitas remaja yang diberikan oleh siswa kelas XI SMA Negeri Jejangkit tentang seksualitas remaja sebelum diberikan penyuluhan tentang kesehatan reproduksi remaja di dominansi oleh kategori sangat rendah $30,2 \%$, kategori rendah $38,1 \%$, kategori sedang 20,6\%. Hal ini dikarenakan karena masih minimnya pengetahuan siswa mengenai kesehatan reproduksi remaja sehingga mempengaruhi persepsi siswa tentang seksualitas remaja. Hal ini menunjukkan bahwa persepsi tentang seksualitas yang dimiliki siswa masih dalam kondisi rendah, sehingga memungkinkan siswa bisa salah berperilaku dalam ruang lingkup seksualitas karena persepsi masih dalam katagori rendah.

Sementara persepsi siswa kelas XI SMA Negeri Jejangkit tentang seksualitas remaja sesudah diberikan penyuluhan kesehatan reproduksi remaja, mengalami peningkatan dimana di dominansi oleh kategori tinggi $47,7 \%$ dan kategori sangat tinggi $20,6 \%$ dan kategori sedang $20,6 \%$ hal ini menunjukkan bahwa perubahan persepsi siswa tentang seksualitas remaja mengalami perubahan seiring dengan meningkatnya pengetahuan yang diperoleh dari materi penyuluhan. Hal ini menunjukan bahwa persepsi tentang seksualitas yang dimiliki siswa sudah baik, sehingga siswa 
akan memiliki perilaku yang benar dalam ruang lingkup seksualitas karena persepsi yang baik.

\section{PENUTUP \\ Kesimpulan}

Berdasarkan hasil penelitian tentang hubungan penyuluhan kesehatan reproduksi remaja dengan persepsi siswa tentang seksualitas remaja pada kelas XI SMA Negeri 1 Jejangkit Kecamatan Jejangkit Kabupaten Barito Kuala dapat disimpulkan bahwa:

a. Hasil pree test diperoleh nilai 6,17 yaitu sebelum dilakukan penyuluhan kesehatan reproduksi remaja pada siswa kelas XI SMA Negeri 1 Jejangkit lebih rendah dari nilai posttest sebesar 8,55 setelah dilakukan penyuluhan kesehatan reproduksi remaja pada siswa. Berdasarkan nilai test tersebut, bahwa penyuluhan kesehatan reproduksi yang dilakukan mempengaruhi pengetahuan siswa tentang kesehatan reproduksi remaja.

b. Persepsi siswa kelas XI SMA Negeri 1 Jejangkit tentang seksualitas remaja sebelum diberikan penyuluhan kesehatan reproduksi remaja sebesar 2,17 lebih tinggi nilai persepsi siswa tentang seksualitas remaja sesudah penyuluhan sebesar 3,73. Nilai persepsi ini menunjukkan adanya peningkatan, sehingga kegiatan penyuluhan kesehatan reproduksi remaja mempunyai pengaruh dalam merubah persepsi siswa mengenai seksualitas remaja mengalami peningkatan nilai rata-rata.

c. Berdasarkan kategori persepsi tentang seksualitas remaja yang diberikan oleh siswa kelas XI SMA Negeri Jejangkit tentang seksualitas remaja sebelum diberikan penyuluhan tentang kesehatan reproduksi remaja menunjukkan bahwa persepsi tentang seksualitas yang dimiliki siswa masih dalam kondisi rendah, sehingga memungkinkan siswa bisa salah berperilaku dalam ruang lingkup seksualitas karena persepsi masih dalam katagori rendah.

d. Persepsi siswa kelas XI SMA Negeri Jejangkit tentang seksualitas remaja sesudah diberikan penyuluhan kesehatan reproduksi remaja, mengalami peningkatan dimana di dominansi oleh kategori tinggi, hal ini menunjukan bahwa persepsi tentang seksualitas yang dimiliki siswa sudah baik, sehingga siswa akan memiliki perilaku yang benar dalam ruang lingkup seksualitas karena persepsi yang baik.

\section{Saran}

Berdasarkan uraian kesimpulan di atas, maka dalam penelitian ini penulis menyarankan bahwa:

1. Bagi sekolah SMA Negeri 1 Jejangkit perlu memberikan pembekalan dan pendidikan mengenai informasi yang benar tentang kesehatan reproduksi remaja dan pandangan mengenai seksualitas remaja kepada anak sehingga anak mengerti dan paham sehingga dengan pengetahuan yang baik dan persepsi yang benar maka siswa lebih dapat membawa diri dan mencegah dari perilaku yang dapat merugikan diri mereka.

2. Penelitian tentang kesehatan reproduksi remaja dan seksualitas remaja ini dapat menjadi rujukan dalam penelitian ke depannya dengan topik lebih berkembang.

\section{DAFTAR PUSTAKA}

Depkes RI. (2007). Profil Kesehatan 2007. Departemen Kesehtan RI .

Intan Kumalasari Dan Iwan Anhyantoro.2012. Kesehatan Reproduksi. Jakarta : Salemba Medika

Marmi.2013. Kesehatan Reproduksi. Yogyakarta :Pustaka Pelajar

Mochtar,R. 2012, Sinopsis Obstetric Fisiologi dan Patologi, jilid 1, Penerbit Buku kedokteran EGC. Jakarta.

Muin, M., Salmah, U., Sarake, M., 2013, „Hubungan Pengetahuan Penyakit Menular Seksual (PMS) Dengan Tindakan Kebersihan Alat Reproduksi Eksternal Remaja Puteri Di SMANasional Makasar Tahun 2013", Available From: http://repository.unhas.ac.id/ bitstream/handle/123456789/5606/JURNA L\%20RHANY.pdf?sequence $=1$. Diakses pada tanggal 15 Mei 2017

Nirwana,A.B. 2011, Psikologi Kesehatan Wanita, Penerbit Nuha Media: Yogyakarta.

Notoatmodjo. 2007.Metodologi PenelitianKesehatan. RinekaCipta. Jakarta

Notoadmojo, S. 2012, Promosi Kesehatan dan Perilaku Kesehatan, Penerbit PT Rineka Cipta: Jakarta.

Okanegara. 2008, "Permasalahan Kespro \& Seksual Remaja Bali", Available From: https://oka negara.wordpress.com/2008/03/02/permas alahankespro- seksual-remaja-bali/. Diakses pada tanggal 28 Mei 2017.

Pieter,H.Z \& Lubis,N.L. 2010, Pengantar Psikologi Untuk Kebidanan, Penerbit Kencana 
Prenada Media Group: Jakarta.

Poltekkes Depkes, 2010. Kesehatan Reproduksi Remaja Dan Solusinya. Jakarta : Salemba Medika

Sugihartono, Dkk .2007. Psikologi Pendidikan. Yogyakarta : UNY Press

Sulistyoningtyas, S., Tamtomo, D. dan Suryani, N. 2016," Pengaruh Penyuluhan Kesehatan Terhadap Sikap Remaja Dalam Merawat Organ Reproduksi" Jurnal Penelitian Humaniora, Vol. 21, No. 2, Oktober 2016: 119-128. Available From : http://journal.uny.ac.id/index. php/humaniora/article/view/13110/pdf. Diakses pada tanggal 05 Juni 2017.

Walgito, Bimo.2004. Pengantar Psikologi Umum. Yogyakarta : Andy

WebMD. 2015, "Abortion - Reasons Women

Choose Abortion". Available From: http://www.webmd .com/women/tc/abortion-reasons-women choose -abortion. Diakses pada tanggal 22 Mei 2017.

Widyastuti, Y., Rahmawati, A. dan Purnaningrum,Y.E. 2009, Kesehatan Reproduksi, Penerbit Fitramaya: Yogyakarta.

Yanti. 2011, Buku Ajar Kesehatan Reproduksi, Pustaka Rihama: Yogyakarta. 